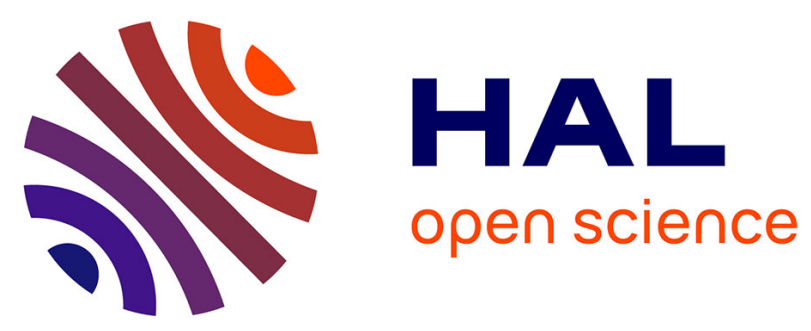

\title{
A new series of lanthanide-based complexes with a bis(hydroxy)benzoxaborolone ligand Synthesis, crystal structure, and magnetic and optical properties
}

Adolf Abdallah, M. Puget, C. Daiguebonne, Y. Suffren, Guillaume Calvez, Kevin Bernot, O. Guillou

\section{To cite this version:}

Adolf Abdallah, M. Puget, C. Daiguebonne, Y. Suffren, Guillaume Calvez, et al.. A new series of lanthanide-based complexes with a bis(hydroxy)benzoxaborolone ligand Synthesis, crystal structure, and magnetic and optical properties. CrystEngComm, 2020, 22 (11), pp.2020-2030. $10.1039 /$ c9ce01592b . hal-02536598

HAL Id: hal-02536598

https://hal-univ-rennes1.archives-ouvertes.fr/hal-02536598

Submitted on 27 Apr 2020

HAL is a multi-disciplinary open access archive for the deposit and dissemination of scientific research documents, whether they are published or not. The documents may come from teaching and research institutions in France or abroad, or from public or private research centers.
L'archive ouverte pluridisciplinaire HAL, est destinée au dépôt et à la diffusion de documents scientifiques de niveau recherche, publiés ou non, émanant des établissements d'enseignement et de recherche français ou étrangers, des laboratoires publics ou privés. 


\section{A new series of lanthanide-based complexes}

with bis(hydroxy)benzoxaborolone ligand: Synthesis, crystal structure, magnetic and optical properties.

Ahmad Abdallah, Marin Puget, Carole Daiguebonne*, Yan Suffren, Guillaume Calvez, Kevin Bernot and Olivier Guillou*.

Univ Rennes, INSA Rennes, CNRS UMR 6226 "Institut des Sciences Chimiques de Rennes", F-35708 Rennes, France.

* To whom correspondence should be addressed. 


\section{ABSTRACT.}

Reactions, in hydro-thermal conditions, between a lanthanide chloride and the sodium salt of 2-carboxyphenylboronic acid lead to a series of lanthanide-based complexes with general chemical formula $\left[\mathrm{Ln}_{2}\left(\mathrm{C}_{7} \mathrm{H}_{5} \mathrm{O}_{2}\right)_{4}\left(\mathrm{C}_{7} \mathrm{O}_{4} \mathrm{H}_{6} \mathrm{~B}\right)_{2} \cdot 4 \mathrm{H}_{2} \mathrm{O}\right]$ with $\mathrm{Ln}=$ Eu-Dy. During the synthetic process, 2-carboxyphenylboronate ligand decomposes leading to benzoate $\left(\mathrm{C}_{7} \mathrm{H}_{5} \mathrm{O}_{2}\right)$ and bis(hydroxy)benzoxaborolone $\left(\mathrm{C}_{7} \mathrm{O}_{2} \mathrm{H}_{6} \mathrm{~B}\right)$. Crystal structure was solved on the basis of the Tb-derivative. It crystalizes in the triclinic system, space group $P-1 \quad\left(n^{\circ} 2\right)$ with $a=9.3329(13) \AA, \quad b=16.012(2) \AA, \quad c=16.212(2) \AA, \quad \alpha=107.789(5)^{\circ}, \quad \beta=90.226(5)^{\circ}$, $\gamma=97.585(5)^{\circ}, V=2284.16(52) \AA^{3}$ and $Z=2$. Crystal structure can be described on the basis of di-lanthanides complexes surrounded by the ligands. Compounds that constitute these series are thermally stable up to $190^{\circ} \mathrm{C}$. Solid-state luminescent properties have been studied in details. Dy-derivative magnetic properties have also been explored. It presents a Single Molecule Magnet behavior. Single crystals of the sodium salt of 2-carboxyphenylboronic acid with chemical formula $\left[\mathrm{Na}\left(\mathrm{C}_{7} \mathrm{O}_{4} \mathrm{H}_{6} \mathrm{~B}\right)\left(\mathrm{H}_{2} \mathrm{O}\right)\right]_{\infty}$ have also been obtained during this study. This compound crystalizes in the orthorhombic system, space group $P 2_{1} 2_{1} 2_{1}$ ( ${ }^{\circ} 19$ ) with $a=4.5881(13) \AA, \quad b=6.5905(16) \AA, c=29.644(8) \AA, V=897.0(4) \AA \AA 3$ and $Z=4$. Crystal structure is $2 \mathrm{D}$ and can be described as zig-zag chains of sodium 2-carboxyphenylboronate bound to each other by coordination water molecules. 


\section{INTRODUCTION.}

For more than a decade, luminescent lanthanide-based coordination polymers have attracted a growing interest because of their various potential fields of technological applications. ${ }^{[1-13]}$ Our group is involved in that field for almost twenty years ${ }^{[14]}$ and the quest for new ligands leading to new lanthanide-based coordination polymers that exhibits original photo-physical properties constitutes a continuous concern. ${ }^{[15-17]}$ Therefore, some years ago, we have decided to explore carboxy-boronic ligands because boronate function can act as a tri-dentate function. ${ }^{[18]}$ Moreover, carboxy-boronic acids present both Lewis and Brönsted acid characters (Scheme 1) and, up to date, only a few examples of crystal structures of coordination polymers based on boronates have been reported. Indeed, most of the reported coordination polymers crystal structures involve alkaline earth metal ions ${ }^{[18-21]}$ or transition metal ions. ${ }^{[22]}$

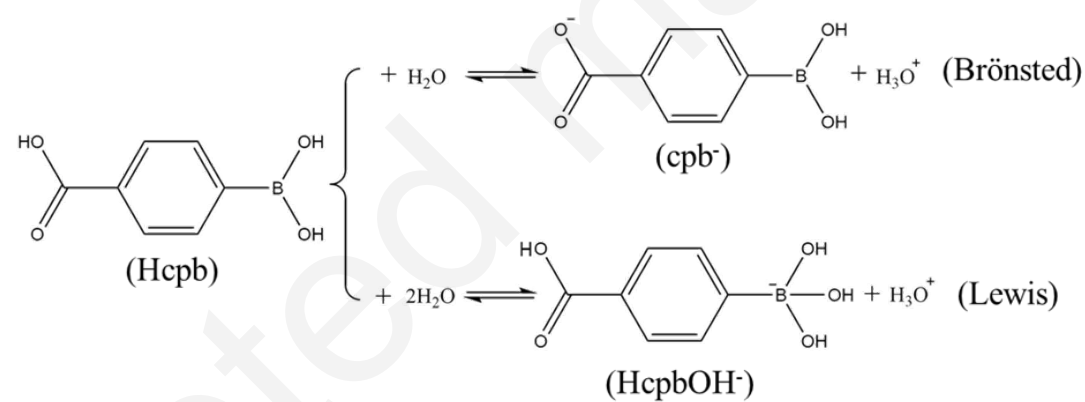

Scheme 1. Illustration of the Lewis and Brönsted acidic character of 4-carboxyphenylboronic acid (Hcpb).

Our work, along this line, has led to the first lanthanide-based coordination polymers with 4-carboxyphenylboronic acid with interesting structural and luminescent properties. ${ }^{\text {[23-24] }}$ In 2017, Yang Z.-R. et al. reported an Eu-based coordination polymer with 5-borono-isophthalic acid. This compound exhibits excellent selective ratiometric fluorescence detection of fluoride ions. ${ }^{[25]}$ On the basis of these results we have decided to explore the synthesis of lanthanide-based coordination polymers based on 2-carboxyphenylboronic acid (Scheme 2). 


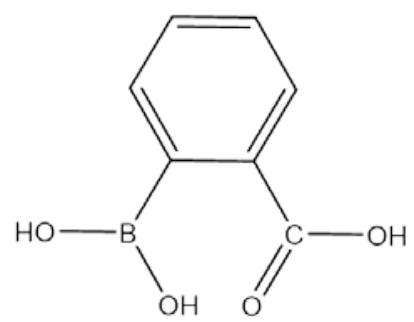

Scheme 2. Schematic representation of 2-carboxyphenylboronic acid hereafter referenced as o-cpbH.

\section{EXPERIMENTAL SECTION.}

\section{Synthesis.}

Lanthanide oxides (99.99\%) have been purchased from Ampere Industry and used without further purification. Lanthanide chlorides have been prepared according to established procedures. $^{[26]}$

\section{Synthesis of $\left(\mathrm{Na}(\mathrm{o}-\mathrm{cpb}) \mathrm{H}_{2} \underline{\mathrm{O}}\right)$}

2-carboxyphenylboronic acid (H(o-cpb)) (97\%) has been purchased from TCI and used without further purification. Microcrystalline powder of its sodium salt $\left(\mathrm{Na}(\mathrm{o}-\mathrm{cpb}) \mathrm{H}_{2} \mathrm{O}\right)$ has been prepared on the basis of a previously described procedure: ${ }^{[24]}$ an aqueous solution of sodium hydroxide $\left(7.10^{-3} \mathrm{~mol}\right.$ in $10 \mathrm{~mL}$ of water) was added dropwise to a suspension in deionized water of the commercial acid $\left(6.10^{-3} \mathrm{~mol}\right.$ in $10 \mathrm{~mL}$ of water). The obtained clear solution was evaporated to dryness. The obtained solid was then dissolved in ethanol and precipitated again by addition of diethylether as a gel. The gel was filtered and dissolved in water and the obtained clear solution evaporated to dryness. Hygroscopic microcrystalline powder that was finally obtained was kept under dry atmosphere. Yield was close to $100 \%$. $\mathrm{C}_{7} \mathrm{H}_{8} \mathrm{BO}_{5} \mathrm{Na}\left(\mathrm{MW}=205.8 \mathrm{~g} \cdot \mathrm{mol}^{-1}\right.$ ) Analysis: (calc.) found: $\mathrm{C}$ (40.8\%) 40.8\%; H (3.9\%) 4.0\%; B (5.2\%) 5.3\%; O (38.9\%) 38.7\%; Na (11.2\%) 11.2\%.

Single-crystals of $\mathrm{Na}(\mathrm{o}-\mathrm{cpb}) \mathrm{H}_{2} \mathrm{O}$ have been obtained by slow evaporation of an aqueous solution of the salt, at room-temperature. Crystal and final structure refinement data are listed in Table 1. Iso-structurality of the microcrystalline powder and of the single-crystal 
has been assumed on the basis of experimental and simulated from the crystal structure X-ray powder diffraction diagrams (Figure S1). Crystal structure, thermal analysis and UV-vis spectrum are depicted in supporting information (Figures S2-S4).

$\left.\underline{\text { Synthesis of }\left[\mathrm{Ln}_{2}\right.} \underline{\mathrm{C}}_{7} \underline{\mathrm{H}}_{5} \underline{\mathrm{O}}_{2} \underline{2}_{4} \underline{\mathrm{C}}_{7} \underline{\mathrm{O}}_{4} \underline{\mathrm{H}}_{6} \underline{\mathrm{B}}_{2} \underline{2}_{2} \underline{4 H}_{2} \underline{\mathrm{O}}\right]$ with Ln $=$ Eu-Dy

Iso-structural coordination polymers with general chemical formula [ $\left.\mathrm{Ln}_{2}\left(\mathrm{C}_{7} \mathrm{H}_{5} \mathrm{O}_{2}\right)_{4}\left(\mathrm{C}_{7} \mathrm{O}_{4} \mathrm{H}_{6} \mathrm{~B}\right)_{2} \cdot 4 \mathrm{H}_{2} \mathrm{O}\right]$ with $\mathrm{Ln}=\mathrm{Eu}-\mathrm{Dy}$ have been obtained by sealing a mixture of a lanthanide chloride $(0.25 \mathrm{mmol})$, of the sodium salt of 2-carboxyphenylboronic acid (0.5 mmol) and of deionized water $(4-10 \mathrm{~mL})$ in a $20 \mathrm{~mL}$ Teflon-line vessel. The mixture was heated at $110^{\circ} \mathrm{C}$ for 3 days and slowly cooled-down to room-temperature $\left(5^{\circ} \mathrm{C} \cdot \mathrm{h}^{-1}\right)$. Colorless hexagonal plate-like single-crystals suitable for single-crystal X-ray diffraction were obtained (Figure 1). Their size depended of the water volume. As expected, the less concentrated the solution was, the bigger the single-crystals were. Yields of the synthesis were very low (a few single crystal per batch). Therefore, iso-structurality of the compounds that constitute this series was assumed on the basis of cell parameters measurements (Table S1). Crystal structure was solved on the basis of the Tb-containing derivative. Crystal and final structure refinement data are listed in Table 1. Elemental analyses are gathered in Table S2.

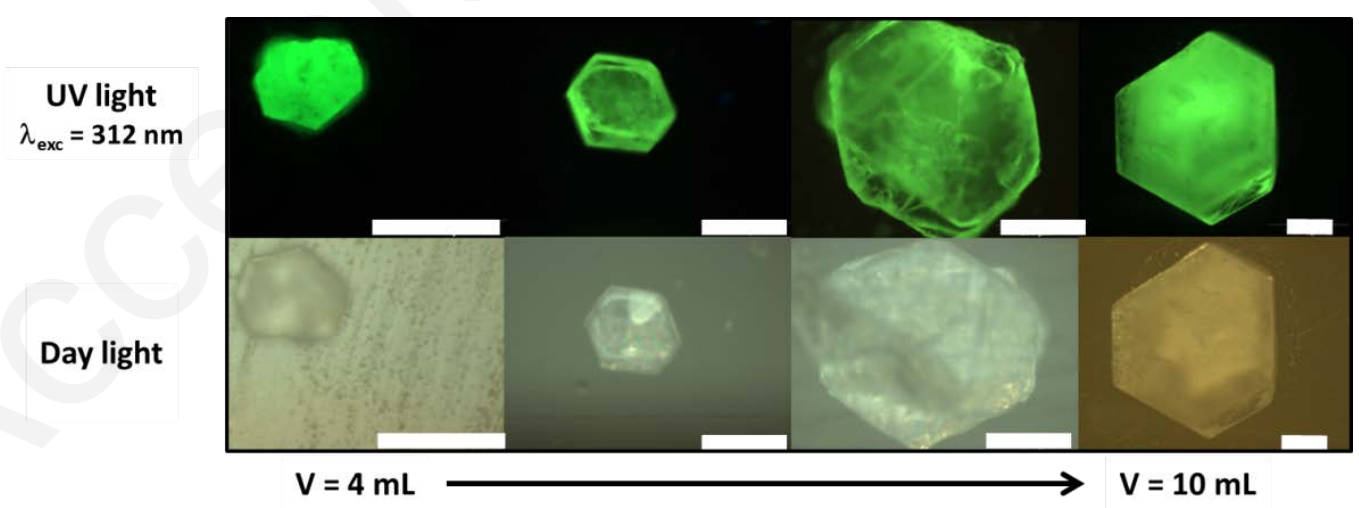

Figure 1. Pictures under UV light (top) and day light (bottom) of single-crystals of $\left[\mathrm{Tb}_{2}\left(\mathrm{C}_{7} \mathrm{H}_{5} \mathrm{O}_{2}\right)_{4}\left(\mathrm{C}_{7} \mathrm{O}_{4} \mathrm{H}_{6} \mathrm{~B}\right)_{2} \cdot 4 \mathrm{H}_{2} \mathrm{O}\right]$ versus the water volume used during the synthesis. White bars represent $200 \mu \mathrm{m}$. 


\section{X-ray diffraction.}

Powder X-ray diffraction diagram was collected on a Panalytical X'pert Pro equipped with an $\mathrm{X}^{\prime}$ Celerator $(45 \mathrm{kV}, 40 \mathrm{~mA}$ for $\mathrm{Cu} \mathrm{K} \alpha(\lambda=1.542 \AA)$ in $\theta / \theta$ mode). Simulated diffractogram was produced with Powdercell and WinPLOTR software programs. ${ }^{\text {[27-29] }}$

Single-crystals were mounted on a Bruker D8 Venture diffractometer. Crystal data collection were performed at $150 \mathrm{~K}$ with $\mathrm{Mo} \mathrm{K}_{\alpha}$ radiation $(\lambda=0.70713 \AA$ ). Crystal structures were solved, using SIR 97, ${ }^{[30]}$ by direct methods. They were refined, using SHELX97 ${ }^{[31]}$ with the aid of WINGX program. ${ }^{[32-33]}$ All non-hydrogen atoms were refined anisotropically. Hydrogen atoms that have been located were located at ideal positions. Absorption corrections were performed using the facilities of WINGX program. ${ }^{[34]}$ Full details of the crystal structures have been deposited with the Cambridge Crystallographic Data Centers under the depositary numbers CCDC-1943082 for $\mathrm{Na}(\mathrm{o}-\mathrm{cpb}) \mathrm{H}_{2} \mathrm{O}$ and CCDC-1909669 for $\left[\mathrm{Tb}_{2}\left(\mathrm{C}_{7} \mathrm{H}_{5} \mathrm{O}_{2}\right)_{4}\left(\mathrm{C}_{7} \mathrm{O}_{4} \mathrm{H}_{6} \mathrm{~B}\right)_{2} \cdot 4 \mathrm{H}_{2} \mathrm{O}\right]$. It can be noticed that there is some residual electronic density in the vicinity of the molecular skeleton. It can be related to the sizeable mosaicity of the single-crystals. Despite great efforts we did not succeed in growing single-crystals of better quality. 


\begin{tabular}{|c|c|c|}
\hline & $\mathrm{Na}(\mathrm{o}-\mathrm{cpb}) \mathrm{H}_{2} \mathrm{O}$ & {$\left[\mathrm{Tb}_{2}\left(\mathrm{C}_{7} \mathrm{H}_{5} \mathrm{O}_{2}\right)_{4}\left(\mathrm{C}_{7} \mathrm{O}_{4} \mathrm{H}_{6} \mathrm{~B}\right)_{2} \cdot 4 \mathrm{H}_{2} \mathrm{O}\right]$} \\
\hline Molecular formula & $\mathrm{C}_{7} \mathrm{H}_{6} \mathrm{BNaO}_{5}$ & $\mathrm{C}_{42} \mathrm{H}_{40} \mathrm{~B}_{2} \mathrm{O}_{20} \mathrm{~Tb}_{2}$ \\
\hline Formula weight (g.mol ${ }^{-1}$ ) & 203.92 & 1204.2 \\
\hline System & Orthorhombic & Triclinic \\
\hline Space group (nº) & $P 2{ }_{1}{ }_{1} 2_{1}(19)$ & $P-1(2)$ \\
\hline$a(\AA)$ & $4.5881(13)$ & $9.3329(13)$ \\
\hline$b(\AA)$ & $6.5905(16)$ & $16.012(2)$ \\
\hline$c(\AA)$ & $29.664(8)$ & $16.212(2)$ \\
\hline$\alpha\left(^{\circ}\right)$ & - & 107.789(5) \\
\hline$\beta\left(^{\circ}\right)$ & - & $90.226(5)$ \\
\hline$\gamma\left({ }^{\circ}\right)$ & - & $97.585(5)$ \\
\hline$V\left(\AA^{3}\right)$ & $897.0(4)$ & $2284.16(52)$ \\
\hline$Z$ & 4 & 2 \\
\hline$D_{\text {calc }}\left(\right.$ g.cm $\left.{ }^{-3}\right)$ & 1.51 & 1.751 \\
\hline$\mu\left(\mathrm{mm}^{-1}\right)$ & 0.165 & 3.15 \\
\hline$R(\%)$ & 4.87 & 5.39 \\
\hline$R_{w}(\%)$ & 14.04 & 15.20 \\
\hline GoF & 1.022 & 1.037 \\
\hline CCDC entry & 1943082 & 1909669 \\
\hline
\end{tabular}

\section{Thermal analyses.}

Thermal analyses of $\mathrm{Na}(\mathrm{o}-\mathrm{cpb}) \mathrm{H}_{2} \mathrm{O}$ and $\left[\mathrm{Tb}_{2}\left(\mathrm{C}_{7} \mathrm{H}_{5} \mathrm{O}_{2}\right)_{4}\left(\mathrm{C}_{7} \mathrm{O}_{4} \mathrm{H}_{6} \mathrm{~B}\right)_{2} \cdot 4 \mathrm{H}_{2} \mathrm{O}\right]$ have both been performed using a Perkin Elmer Pyris Diamond TGA/TDA, between $20^{\circ} \mathrm{C}$ and $950^{\circ} \mathrm{C}$ in platinum crucibles under $\mathrm{N}_{2}$ atmosphere.

\section{Optical measurements.}

Solid-state emission and excitation spectra have been measured on a Horiba Jobin-Yvon Fluorolog III fluorescence spectrometer equipped with a Xe lamp $450 \mathrm{~W}$ and a UV-Vis photomultiplier (Hamamatsu R928, sensitivity 190-860 nm) and an IR-photodiode cooled by liquid nitrogen (InGaAs, sensitivity $800-1600 \mathrm{~nm}$ ). Most of the luminescence spectra were recorded at room-temperature. The emission/excitation spectra recordings were realized on powder samples introduced in cylindrical quartz cells of $0.7 \mathrm{~cm}$ diameter and $2.4 \mathrm{~cm}$ height, which were placed directly inside the integrating sphere, or on powder samples 
pasted on copper plates with silver glue. The phosphorescence of the Gd-based microcrystalline powders, introduced in quartz capillary tubes, has been measured in a cold finger at $77 \mathrm{~K}$ (Dewar + liquid nitrogen). Quantum yield measurements were performed using a Jobin-Yvon integrating sphere $\left(\Phi=\left(E_{c}-E_{a}\right) /\left(L_{a}-L_{c}\right)\right.$ with $E_{c}$ being the integrated emission spectrum of the sample, $E_{a}$ the integrated "blank" emission spectrum, $L_{a}$ the "blank" absorption and $\mathrm{L}_{\mathrm{c}}$ the sample absorption at the excitation wavelength). Integrated sphere has been calibrated using europium tris-dipiconilate in the solid-state $\mathrm{e}^{[35]}$ and cesium dipiconilate in the liquid-sate. ${ }^{[36]}$ Luminescence decays $(\tau>10 \mu \mathrm{s})$ have also been measured at room-temperature using this apparatus with a Xenon flash lamp (phosphorescence mode). Lifetimes are averages of two or three independent determinations. Appropriate filters were used to remove the residual excitation laser light, the Rayleigh scattered light and associated harmonics from spectra. All spectra were corrected for the instrumental response function.

Absorption spectra were recorded with a Perkin Elmer Lambda 650 UV/vis spectrometer equipped with a $60 \mathrm{~mm}$ integrating sphere at room-temperature.

\section{Magnetic measurements}

A Quantum Design MPMS SQUID magnetometer has been used to perform magnetic measurements on powder pressed into Teflon pellet in order to avoid in-field orientation of the crystallites. All measurements were corrected for the diamagnetic contribution of the sample as calculated from Pascal's constants. 


\section{RESULTS AND DISCUSSION}

\section{Crystal structure of $\left[\mathrm{Ln}_{2}\left(\mathrm{C}_{7} \mathrm{H}_{5} \mathrm{O}_{2}\right)_{4}\left(\mathrm{C}_{7} \mathrm{O}_{4} \mathrm{H}_{6} \mathrm{~B}\right)_{2} \cdot 4 \mathrm{H}_{2} \mathrm{O}\right]$ with $\mathrm{Ln}=\mathrm{Eu}-\mathrm{Dy}$.}

Reactions in hydrothermal conditions of a lanthanide chloride ( $\mathrm{Ln}=\mathrm{Eu}$-Dy) and the sodium salt of 2-carboxyphenylboronic acid lead to a family of iso-structural lanthanide-based complexes (Scheme 3).

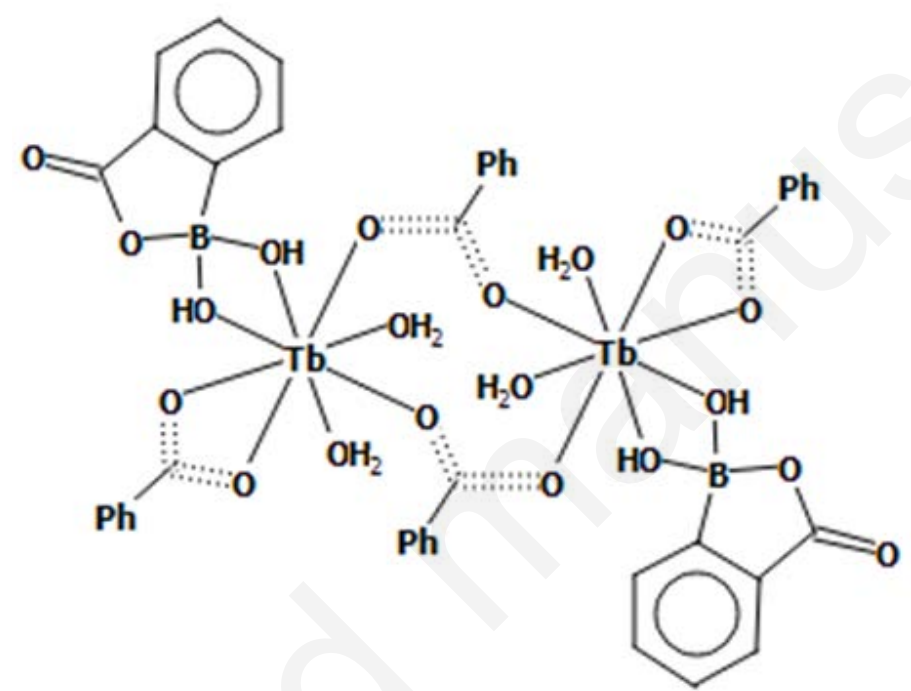

Scheme 3. Schematic representation of the di-nuclear complex $\left[\mathrm{Tb}_{2}\left(\mathrm{C}_{7} \mathrm{H}_{5} \mathrm{O}_{2}\right)_{4}\left(\mathrm{C}_{7} \mathrm{O}_{4} \mathrm{H}_{6} \mathrm{~B}\right)_{2} \cdot 4 \mathrm{H}_{2} \mathrm{O}\right]$.

The crystal structure has been solved on the basis of the Tb-derivative. It can be described on the basis of di-lanthanide complexes. During the synthesis, 2-carboxyphenylboronate ligand decomposed and led to benzoate in one hand and bis(hydroxy)benzoxaborolone in the other hand. ${ }^{[18]}$ Thermal analyses of $\left[\mathrm{Tb}_{2}\left(\mathrm{C}_{7} \mathrm{H}_{5} \mathrm{O}_{2}\right)_{4}\left(\mathrm{C}_{7} \mathrm{O}_{4} \mathrm{H}_{6} \mathrm{~B}\right)_{2} \cdot 4 \mathrm{H}_{2} \mathrm{O}\right]$ (Figure S5) are in agreement with the crystal structure. Indeed the dehydration of the $-\mathrm{B}(\mathrm{OH})_{2}$ groups is also observed leading to a total departure of 6 water molecules per formula unit (9\%).

There is only one crystallographycally independent $\mathrm{Tb}^{3+}$ ion in the crystal structure. It is eight coordinated (Figure 2) by two oxygen atoms from a bidentate benzoate, two oxygen 
atoms from two bridging benzoate, two oxygen atoms from a bis(hydroxy)benzoxaborolone molecule and two oxygen atoms from two coordination water molecules that form a slightly distorted dodecahedron. The two lanthanide ions that belong to the same di-lanthanide complex are linked by two bridging carboxylate functions from two benzoate ligands and by intramolecular hydrogen bonds that involve coordination water molecules (Figure 2). Intra-molecular intermetallic distance is $4.8688(7) \AA$. The complex is globally planar and elongated along the $c$-axis (Figure 2). The molecular stacking is insured via a complex hydrogen-bonds network that involve -OH groups from the boronic function, the oxygen atom of the ketone function, oxygen atoms from the carboxylate functions and coordination water molecules.

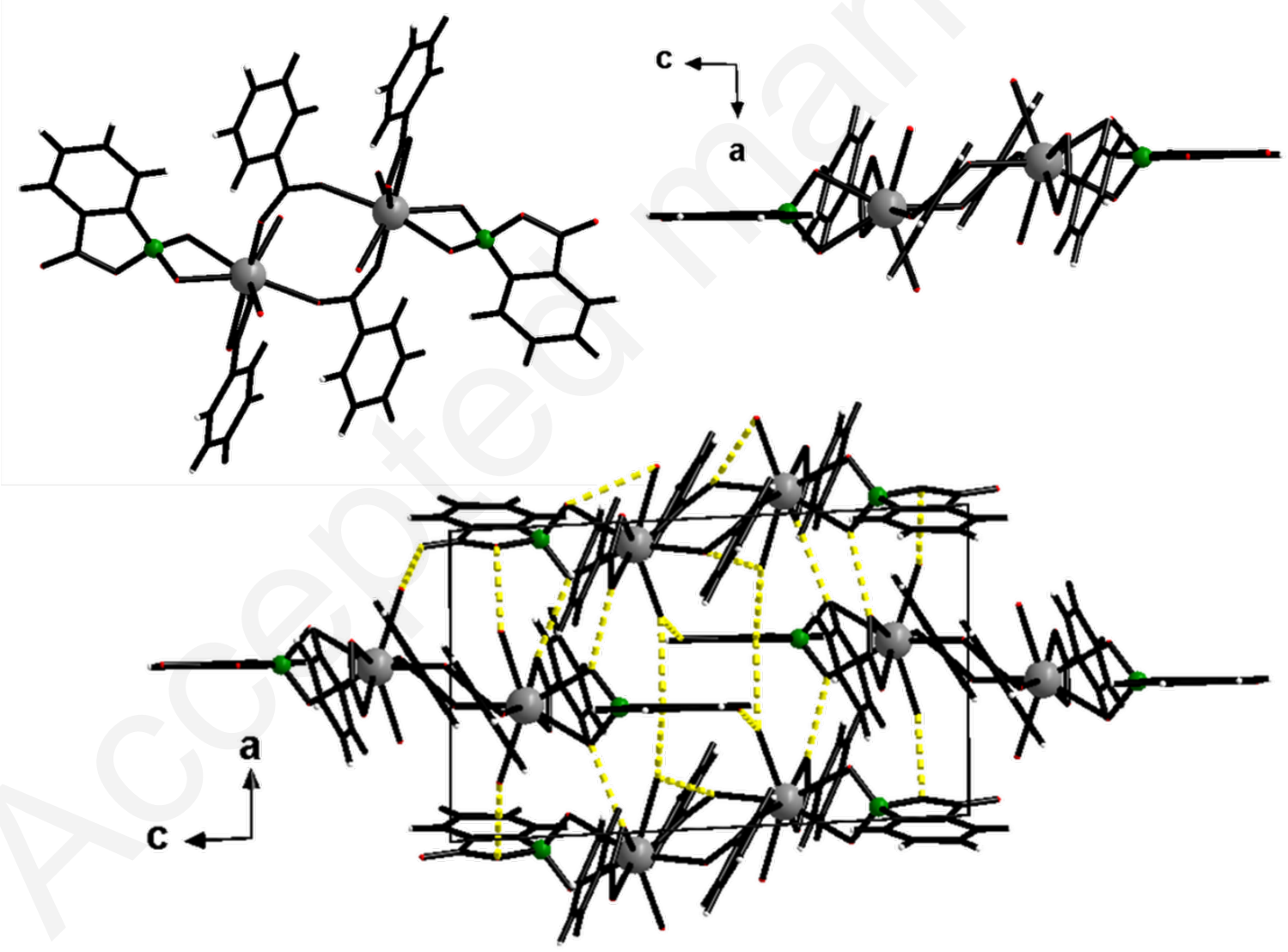

Figure 2. Top: projection views along the $a$-axis (left) and the $b$-axis (right) of a complex $\left[\mathrm{Tb}_{2}\left(\mathrm{C}_{7} \mathrm{H}_{5} \mathrm{O}_{2}\right)_{4}\left(\mathrm{C}_{7} \mathrm{O}_{4} \mathrm{H}_{6} \mathrm{~B}\right)_{2} \cdot 4 \mathrm{H}_{2} \mathrm{O}\right]$. Bottom: Projection view along the $b$-axis of an extended unit cell of $\left[\mathrm{Tb}_{2}\left(\mathrm{C}_{7} \mathrm{H}_{5} \mathrm{O}_{2}\right)_{4}\left(\mathrm{C}_{7} \mathrm{O}_{4} \mathrm{H}_{6} \mathrm{~B}\right)_{2} \cdot 4 \mathrm{H}_{2} \mathrm{O}\right]$. Most relevant hydrogen-bonds are symbolized by yellow broken line 


\section{Luminescent properties of $\left[\mathrm{Ln}_{2}\left(\mathrm{C}_{7} \mathrm{H}_{5} \mathrm{O}_{2}\right)_{4}\left(\mathrm{C}_{7} \mathrm{O}_{4} \mathrm{H}_{6} \mathrm{~B}\right)_{2} \cdot 4 \mathrm{H}_{2} \mathrm{O}\right]$ with $\mathrm{Ln}=\mathrm{Eu}-\mathrm{Dy}$.}

Energies of the lowest singlet and triplet excited states of the ligands have been estimated on the basis of the excitation and emission spectra of the Gd-derivative recorded at $77 \mathrm{~K}$. They have been estimated by referring to the wavelength of the excitation edge $\left(E_{1} \pi_{-}{ }^{1} \pi^{*}=335 \mathrm{~nm}=29850 \mathrm{~cm}^{-1}\right.$ ) and of the shortest wavelength of the phosphorescent band of the ligands $\left(\mathrm{E}_{1} \pi_{-}{ }^{3} \pi^{*}=370 \mathrm{~nm}=27000 \mathrm{~cm}^{-1}\right.$ ), respectively (Figure 3). ${ }^{37-39}$ Empirical Reinhoudt's rules ${ }^{40-41}$ predict that these values are not supposed to favor efficient intercrossing system process. Indeed, difference between these two excited states $\left(\Delta \mathrm{E}=\mathrm{E}_{1} \pi^{*}-\right.$ $\mathrm{E}_{3_{\pi^{*}}}=2850 \mathrm{~cm}^{-1}$ ) is smaller than $5000 \mathrm{~cm}^{-1}$. However, it must be noticed that in this complex there are two distinct ligands. This makes questionable a precise experimental assignation of the excitation and emission peaks.

Excitation spectrum of the Gd-based complex presents a maximum centered at $326 \mathrm{~nm}$ that is also observed in excitation spectra of the Tb- and Dy-derivatives (Figures 4 and 5). This strongly suggests that one out of the two ligands acts as an efficient antenna toward these two lanthanide ions. ${ }^{42}$ In the following, it has been assumed that this excitation peak is related to bis(hydroxy)benzoxaborolone ligand because benzoate absorption peak is expected at lower wavelength $(<300 \mathrm{~nm}){ }^{43-44}$ 


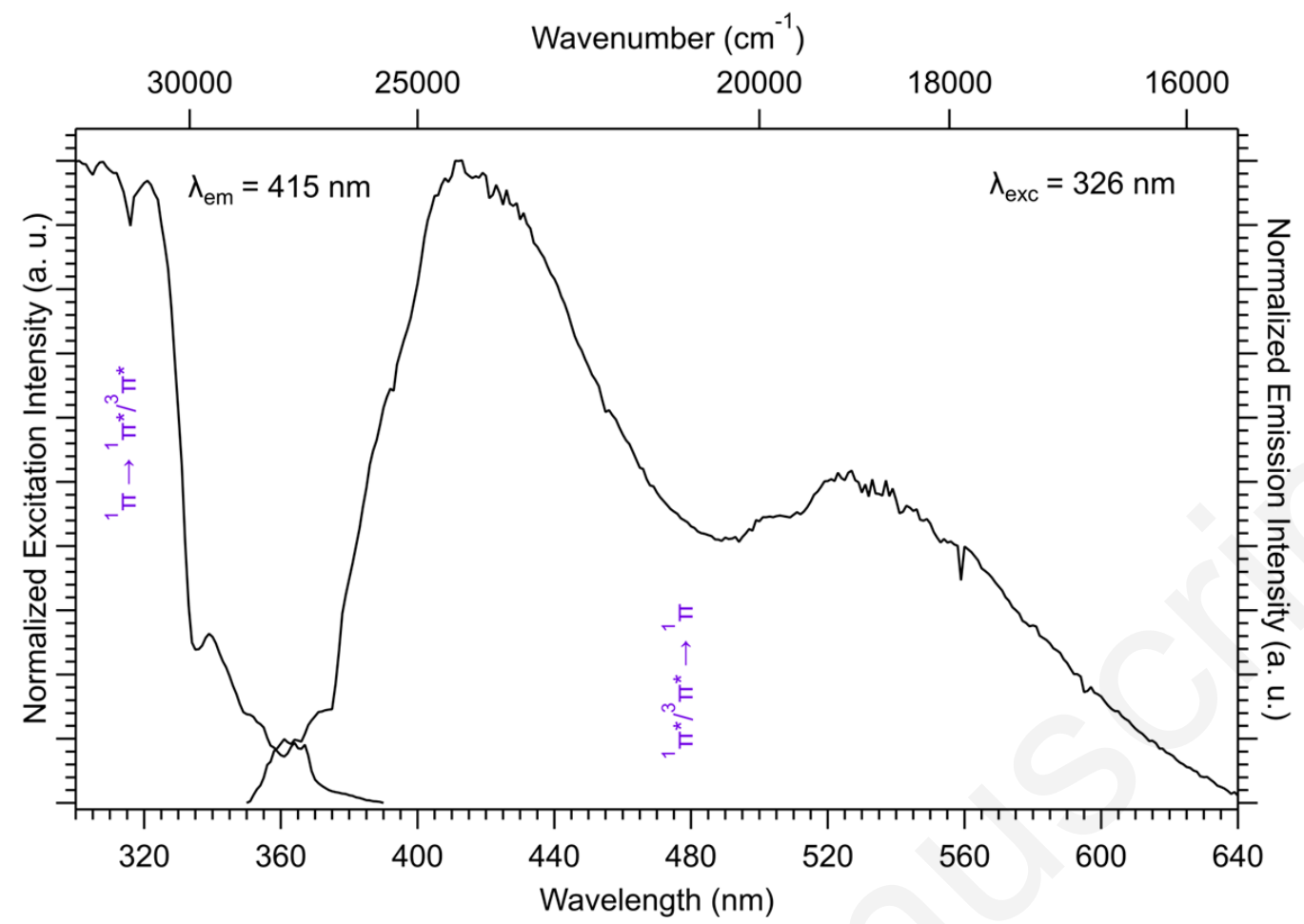

Figure 3. Solid state excitation and emission spectra of $\left[\mathrm{Gd}_{2}\left(\mathrm{C}_{7} \mathrm{H}_{5} \mathrm{O}_{2}\right)_{4}\left(\mathrm{C}_{7} \mathrm{O}_{4} \mathrm{H}_{6} \mathrm{~B}\right)_{2} \cdot 4 \mathrm{H}_{2} \mathrm{O}\right]$ recorded at $77 \mathrm{~K}$. Luminescence lifetime at $77 \mathrm{~K}$ is $3.1(1) \mathrm{ms}$ under excitation at $326 \mathrm{~nm}$.

Emission spectra of $\left[\mathrm{Tb}_{2}\left(\mathrm{C}_{7} \mathrm{H}_{5} \mathrm{O}_{2}\right)_{4}\left(\mathrm{C}_{7} \mathrm{O}_{4} \mathrm{H}_{6} \mathrm{~B}\right)_{2} \cdot 4 \mathrm{H}_{2} \mathrm{O}\right]$ have been recorded under two excitation wavelengths (Figure 4). Emission spectrum measured by irradiation of the ligand $\left(\lambda_{\text {exc }}=326 \mathrm{~nm}\right.$ ) is much more intense than the one obtained by direct excitation of the lanthanide ion $\left(\lambda_{\text {exc }}=378.5 \mathrm{~nm} ;{ }^{7} \mathrm{~F}_{6} \rightarrow{ }^{5} \mathrm{G}_{6}\right)$. Emission spectrum shows all the characteristic emission peaks of $\mathrm{Tb}^{3+}$ ion $\left({ }^{5} \mathrm{D}_{4} \rightarrow{ }^{7} \mathrm{~F}_{6-0}\right)$ and is dominated by the ${ }^{5} \mathrm{D}_{4} \rightarrow{ }^{7} \mathrm{~F}_{5}$ transition $(543.5 \mathrm{~nm})$ that induces green luminescence. Overall quantum yield $\left(Q_{\mathrm{Tb}}^{\mathrm{Ligand}}\right)$ and luminescence lifetime $\left(\tau_{\mathrm{obs}}\right)$ have been measured: $Q_{\mathrm{Tb}}^{\text {Ligand }}=79(6) \%$ and $\tau_{\mathrm{obs}}=0.84(1) \mathrm{ms}$ ( $\lambda_{\mathrm{ex}}=326 \mathrm{~nm}$ or $378.5 \mathrm{~nm}$; room-temperature). This sizeable overall quantum yield is in agreement with empirical Latva's rules ${ }^{45-46}$ that predict efficient Ligand-to- $\mathrm{Tb}^{3+}$ energy transfer without significant back-transfers $\left(\Delta \mathrm{E}\left({ }^{3} \pi^{*}{ }_{-}^{5} \mathrm{D}_{4}\right)=27000-20500=6500 \mathrm{~cm}^{-1}\right)$. It also suggests that part of the energy absorbed by the ligand is directly transferred from ligand first excited singlet state to $\mathrm{Tb}^{3+}$ emitting levels. 


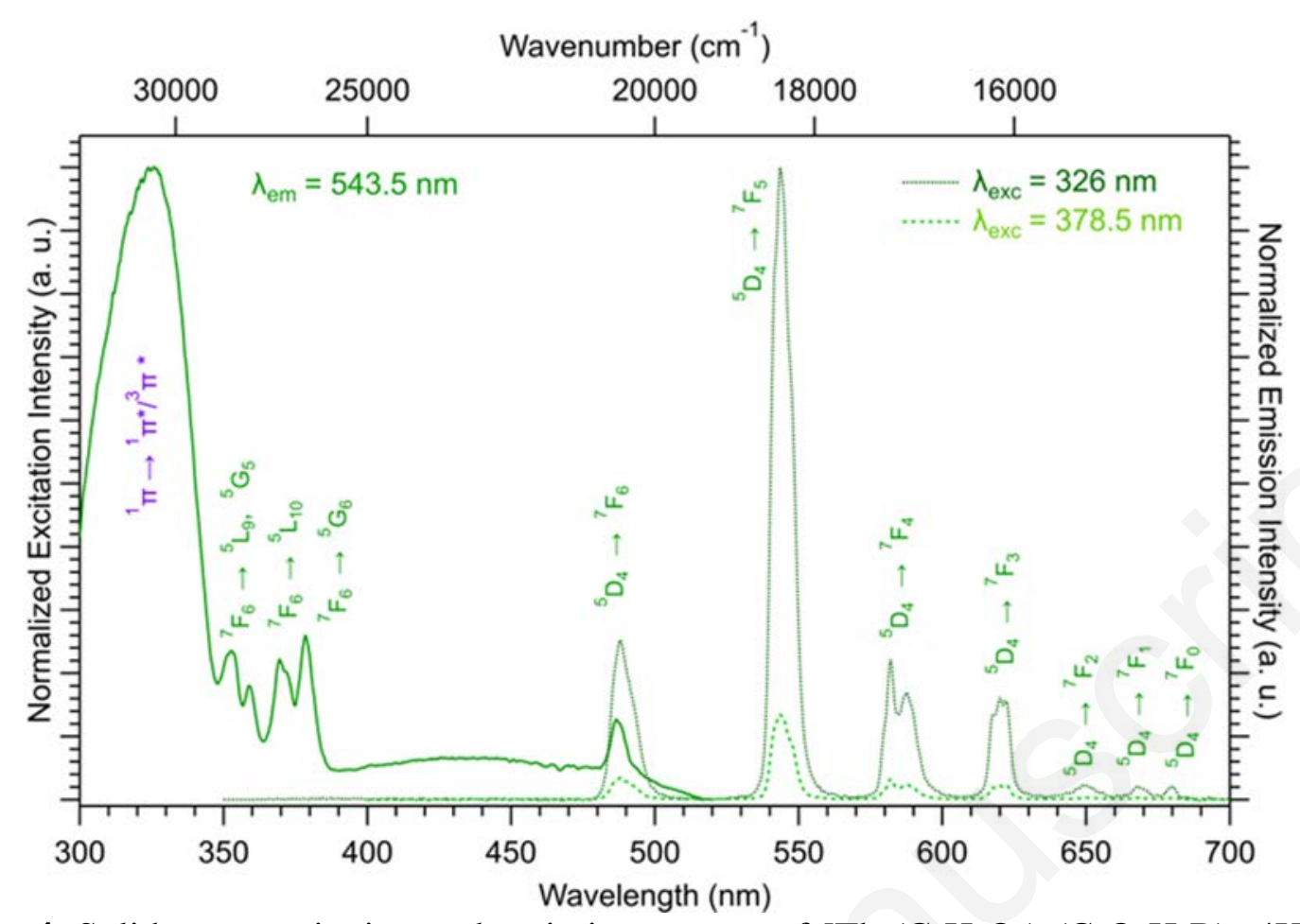

Figure 4. Solid state excitation and emission spectra of $\left[\mathrm{Tb}_{2}\left(\mathrm{C}_{7} \mathrm{H}_{5} \mathrm{O}_{2}\right)_{4}\left(\mathrm{C}_{7} \mathrm{O}_{4} \mathrm{H}_{6} \mathrm{~B}\right)_{2} \cdot 4 \mathrm{H}_{2} \mathrm{O}\right]$ at room-temperature. Luminescence lifetime is $0.84(1) \mathrm{ms}$ for both excitation wavelengths.

Excitation spectrum of the Dy-based complex also exhibits a broad excitation peak centered at $326 \mathrm{~nm}$ which suggests that antenna effect is efficient also for this complex. Emission spectra have been recorded in both the visible and the IR regions (Figure 5). In the visible domain it exhibits the characteristic transitions of the Dy ${ }^{3+}$ ions: ${ }^{4} \mathrm{~F}_{9 / 2} \rightarrow{ }^{6} \mathrm{H}_{15 / 2-9 / 2}$. It is dominated by the ${ }^{4} \mathrm{~F}_{9 / 2} \rightarrow{ }^{6} \mathrm{H}_{13 / 2}$ transition at $574 \mathrm{~nm}$ which produces a yellowish emission. In the IR domain emission spectrum exhibits characteristic transitions of the $\mathrm{Dy}^{3+}$ ion: ${ }^{4} \mathrm{~F}_{9 / 2} \rightarrow{ }^{6} \mathrm{H}_{7 / 2-5 / 2}$ and ${ }^{4} \mathrm{~F}_{9 / 2} \rightarrow{ }^{6} \mathrm{~F}_{9 / 2-5 / 2}$. These transitions are of weak intensities. This could be related to the weak energy gap between the luminescent $D y^{3+}$ energy state $\left({ }^{4} F_{9 / 2}\right)$ and the receiving level that favors non-radiative de-excitation. ${ }^{39}$ These weak intensities are confirmed by low quality (low signal/noise ratio) of the excitation spectrum recorded at $836 \mathrm{~nm}$ (Figure 5 bottom). 

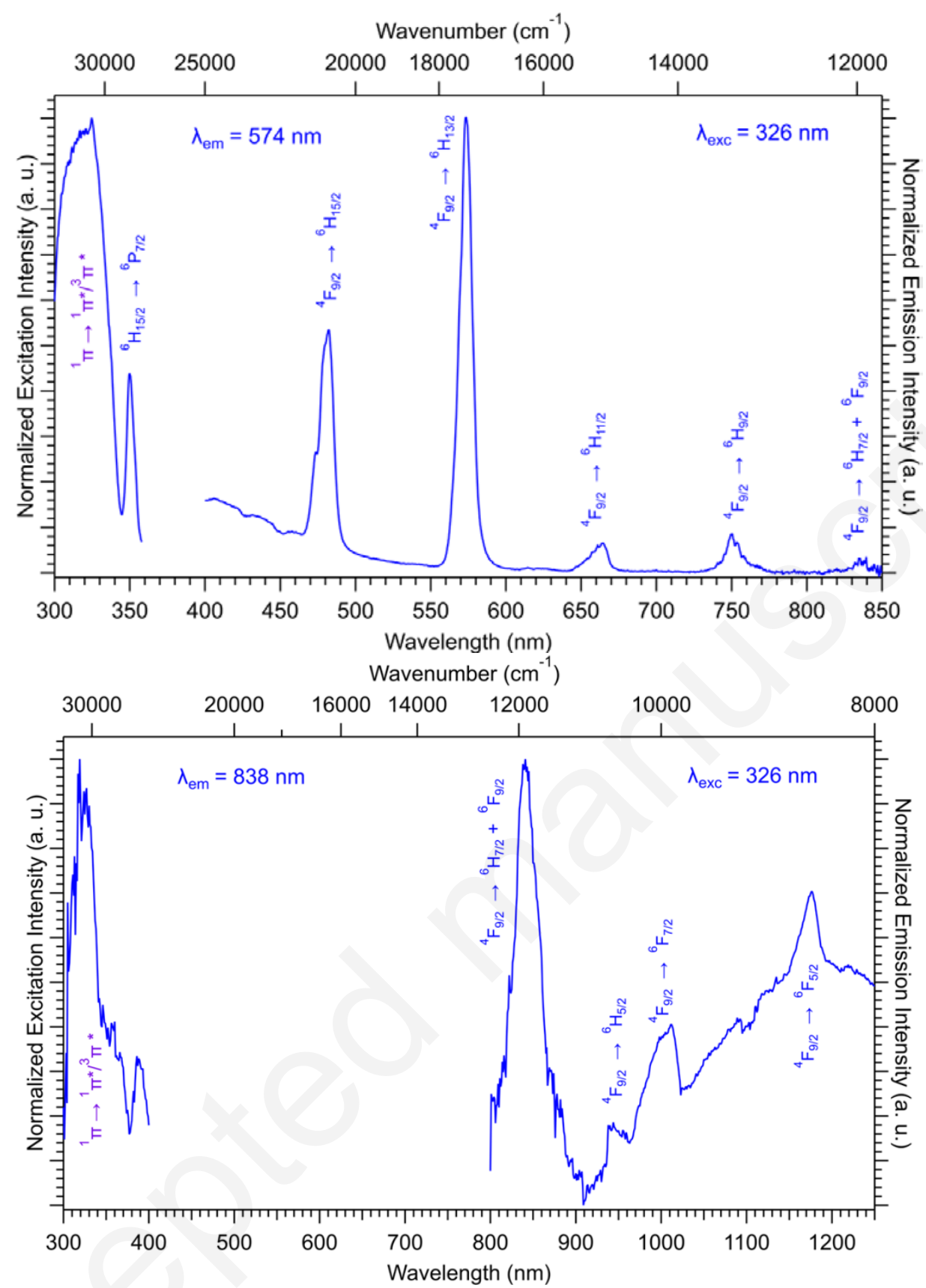

Figure 5. Solid state excitation and emission spectra of $\left[\mathrm{Dy}_{2}\left(\mathrm{C}_{7} \mathrm{H}_{5} \mathrm{O}_{2}\right)_{4}\left(\mathrm{C}_{7} \mathrm{O}_{4} \mathrm{H}_{6} \mathrm{~B}\right)_{2} \cdot 4 \mathrm{H}_{2} \mathrm{O}\right]$ at room-temperature. Luminescence has been observed in both visible (top) and IR (bottom) domains.

Solid-state excitation and emission spectra of $\left[\mathrm{Eu}_{2}\left(\mathrm{C}_{7} \mathrm{H}_{5} \mathrm{O}_{2}\right)_{4}\left(\mathrm{C}_{7} \mathrm{O}_{4} \mathrm{H}_{6} \mathrm{~B}\right)_{2} \cdot 4 \mathrm{H}_{2} \mathrm{O}\right]$ have been recorded (Figure 6). Excitation spectrum doesn't present the characteristic band attributed to the ligand $(326 \mathrm{~nm})$ and emission spectrum under direct excitation of the $\mathrm{Eu}^{3+}$ ion (394 $\mathrm{nm} ;{ }^{7} \mathrm{~F}_{0} \rightarrow{ }^{5} \mathrm{~L}_{6}$ ) is much more intense than emission spectrum recorded under ligand excitation. Emission spectrum exhibits all the characteristic transition of $\mathrm{Eu}^{3+}$ ion: 
${ }^{5} \mathrm{D}_{0} \rightarrow{ }^{7} \mathrm{~F}_{0-6}$. It is dominated by the ${ }^{5} \mathrm{D}_{0} \rightarrow \mathrm{F}_{2}$ transition $(616 \mathrm{~nm})$ that produces a red luminescence.

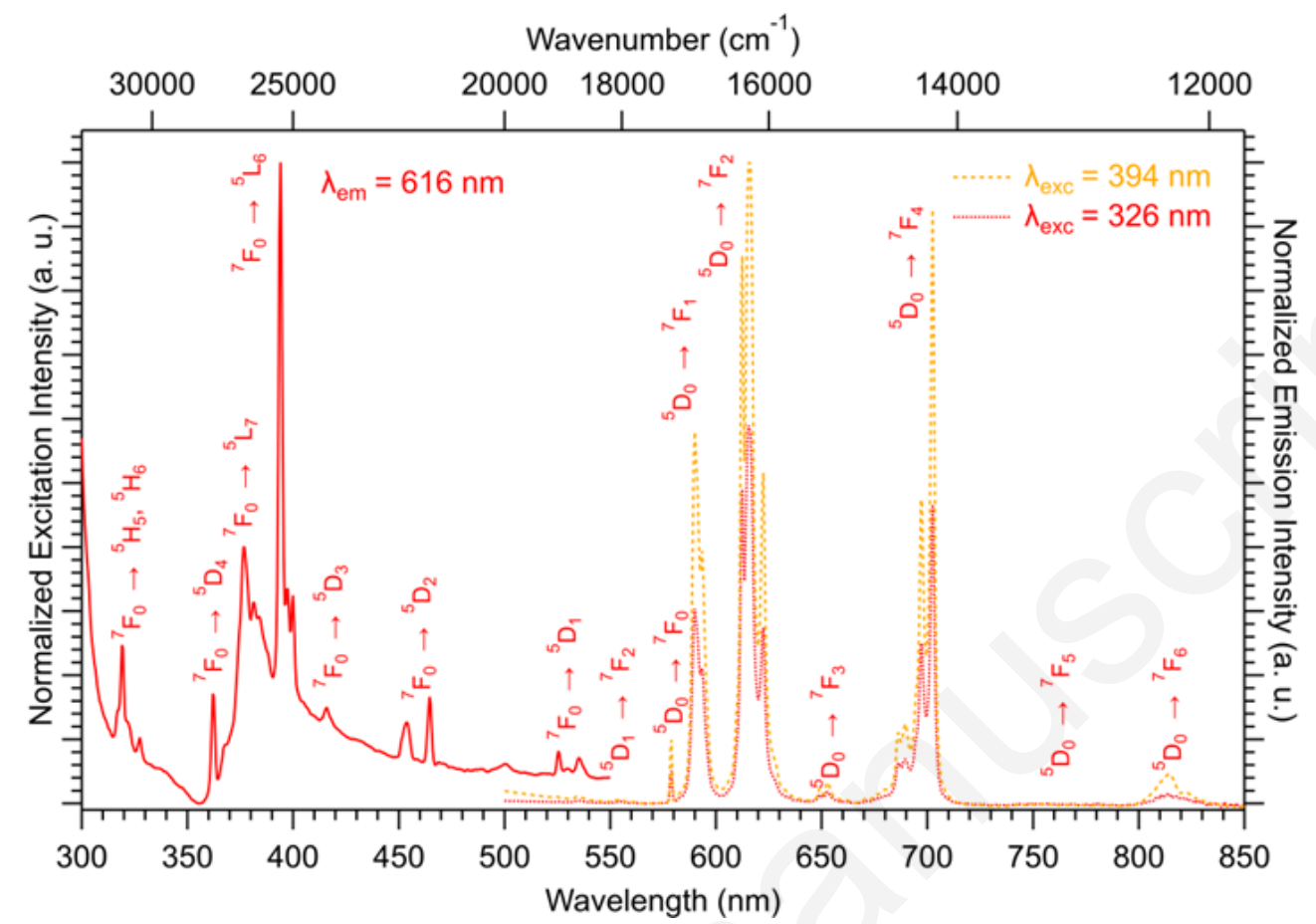

Figure 6. Solid state excitation and emission spectra of $\left[\mathrm{Eu}_{2}\left(\mathrm{C}_{7} \mathrm{H}_{5} \mathrm{O}_{2}\right)_{4}\left(\mathrm{C}_{7} \mathrm{O}_{4} \mathrm{H}_{6} \mathrm{~B}\right)_{2} \cdot 4 \mathrm{H}_{2} \mathrm{O}\right]$ at room-temperature. Luminescence lifetime is $0.28(1) \mathrm{ms}$ for both excitation wavelengths.

Overall quantum yield $\left(Q_{E u}^{\text {Ligand }}\right)$ and intrinsic quantum yields $\left(Q_{E u}^{E u}\right)$ have been measured: $Q_{E u}^{\text {Ligand }}=0.62(2) \%$ and $Q_{E u}^{E u}=20.9(6) \%$. Sensitization efficiency $\left(\eta_{\text {sens }}=3.0 \%\right)$ has been calculated according to relationship: $:^{39}$

$\mathrm{Q}_{\mathrm{Eu}}^{\mathrm{Ligand}}=\eta_{\text {sens }} \times \mathrm{Q}_{\mathrm{Eu}}^{\mathrm{Eu}}$

This low value confirms that antenna effect is inefficient for the Eu-based complex. This can be related to a photo-induced electron transfer (PET) mechanism that occurs when a donating ion is in the vicinity of an easily reducible lanthanide ion such as $\mathrm{Eu}^{3+} .^{38,47-50}$ This strongly supports the assumption that bis(hydroxy)benzoxaborolone is responsible for the antenna effect observed for the Tb- and Dy-derivatives because benzoate ligand can't be involved in a PET mechanism. 


\section{Magnetic properties of $\left[\mathrm{Dy}_{2}\left(\mathrm{C}_{7} \mathrm{H}_{5} \mathrm{O}_{2}\right)_{4}\left(\mathrm{C}_{7} \mathrm{O}_{4} \mathrm{H}_{6} \mathrm{~B}\right)_{2} \cdot 4 \mathrm{H}_{2} \mathrm{O}\right]$}

Lanthanide-based molecules are good candidate to observe Single-Molecule Magnet (SMM) behavior. ${ }^{51}$ Such behavior is seen when an anisotropic magnetic molecule is magnetically isolated from its neighbors. It that case, it can present magnetic slow relaxation and thus behave as a magnet at a molecular level.

In an appropriate coordination environment the Dy ${ }^{\mathrm{III}}$ ion can be extremely anisotropic ( $g_{x}=0, g_{y}=0, g_{z}=20$ if a $S=1 / 2$ ground state is considered) and most of Ln-SMMs are based on this ion. One of the strategies to obtain Dy-SMM is to synthesize Dy ${ }^{\text {III }}$ dimers ${ }^{52-54}$ where Dy-Dy intramolecular magnetic interaction can influence the SMM properties. ${ }^{55-59}$

$\left[\mathrm{Dy}_{2}\left(\mathrm{C}_{7} \mathrm{H}_{5} \mathrm{O}_{2}\right)_{4}\left(\mathrm{C}_{7} \mathrm{O}_{4} \mathrm{H}_{6} \mathrm{~B}\right)_{2} \cdot 4 \mathrm{H}_{2} \mathrm{O}\right]$ is a dimer in which Dy ${ }^{\mathrm{III}}$ ions are eight coordinated by oxygen ligands. Continuous Shape measurement $(\mathrm{CShM})^{60-61}$ shows that the coordination polyhedron of Dy1 and Dy2 are highly similar and are triangular dodecahedron $\left(D_{2} d\right.$ site symmetry, $\mathrm{CShM}=2.099$ and 2.102 for Tb1 and Tb2, respectively, Table S3). This coordination polyhedron is not particularly suitable for the observation of SMM behavior. ${ }^{62-66}$ However, one can see that the height oxygens are very different on the electrostatic point of view. Indeed, the most charged oxygens atoms are above, below and in the plane of the $\mathrm{B}(\mathrm{OH})_{2}$ clamp. This means that the Dy ${ }^{\mathrm{III}}$ feels an electrostatic field that is axial or equatorial, with almost no transverse component (Figure 7). If the axial electrostatic field is strong enough a SMM behavior could be expected because it stabilizes the Dy ${ }^{\mathrm{III}}$ highly anisotropic magnetic ground state $\left(M_{J}= \pm 15 / 2\right)$. 

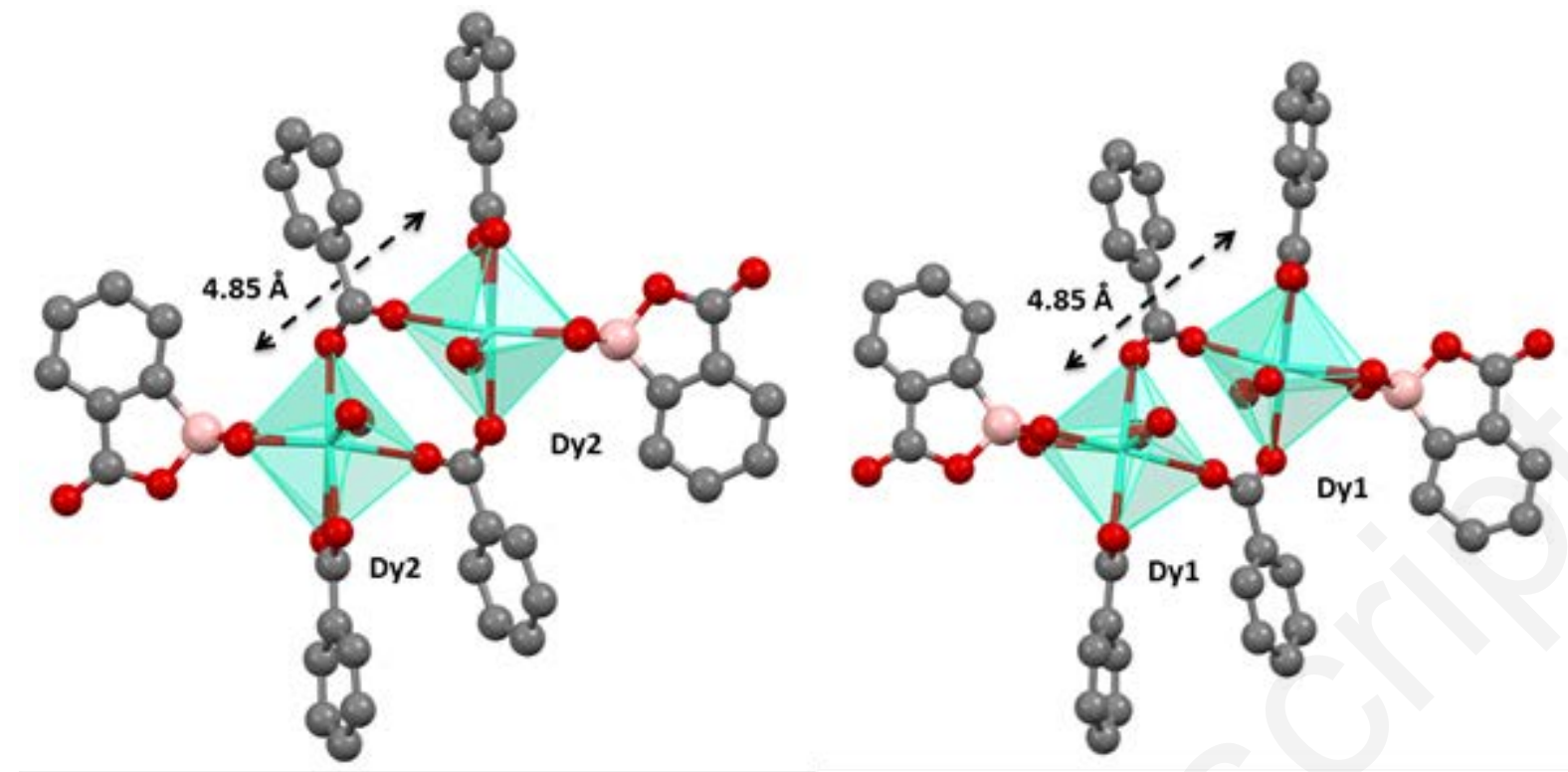

Figure 7. Representation of the two dimers found in $\left[\mathrm{Dy}_{2}\left(\mathrm{C}_{7} \mathrm{H}_{5} \mathrm{O}_{2}\right)_{4}\left(\mathrm{C}_{7} \mathrm{O}_{4} \mathrm{H}_{6} \mathrm{~B}\right)_{2} \cdot 4 \mathrm{H}_{2} \mathrm{O}\right]$ with Dy coordination polyhedron and Dy-Dy distances highlighted.

Static magnetic measurements have been performed and room-temperature $\chi_{M} T_{(300 K)}=28.29$ emu.K.mol ${ }^{-1}$, close to the expected value of 28.34 emu.K.mol ${ }^{-1}$ for two isolated Dy ${ }^{\mathrm{III}}$ ions $\left(\mathrm{J}=5 / 2, \mathrm{~g}_{\mathrm{j}}=4 / 3\right)$ (Figure S6). As the temperature is lowered, a continuous decrease of $\chi_{\mathrm{M}} \mathrm{T}$ is observed that is a consequence of the depopulation of the Dy ${ }^{\mathrm{III}}$ Stark sub-levels. The Dy-Dy magnetic coupling is expected to be very weak because i) carboxylate clamps in $\eta_{2}$ coordination mode are known to be inefficient in transmitting magnetic exchange interactions ii) Dy1-Dy1 and Dy2-Dy2 distances are $4.84 \AA$, too long to observe any significant intramolecular magnetic coupling.

Dynamic magnetic measurements show not out-of phase ( $\chi_{M}$ ”) magnetic relaxation in absence of a magnetic dc field. However, as a field is applied a slow relaxation is observed that is optimized for $\mathrm{H}_{\mathrm{dc}}=1200$ Oe (Figure S7). With this field, temperature dependent dynamic measurements are performed and clear magnetic slow relaxation is observed between 1.8 and $10 \mathrm{~K}$ (Figure 8 and S8). The relaxation times are extracted considering and modified Debye law ${ }^{67}$ (Table S4) and an Arrhenius plot is reported in Figure 8. In the high temperature regime, an Orbach magnetic relaxation can be considered and the relaxation time 
is $\tau=\tau_{0} \exp \left(\mathrm{U}_{\mathrm{eff}} / \mathrm{k}_{\mathrm{B}} \mathrm{T}\right)$ where $\tau_{0}$ is the characteristic relaxation time, $\mathrm{U}_{\text {eff }}$ is the activation energy required for the spin reversal and $k_{\mathrm{B}}$ is the Boltzmann constant. For $\left[\mathrm{Dy}_{2}\left(\mathrm{C}_{7} \mathrm{H}_{5} \mathrm{O}_{2}\right)_{4}\left(\mathrm{C}_{7} \mathrm{O}_{4} \mathrm{H}_{6} \mathrm{~B}\right)_{2} \cdot 4 \mathrm{H}_{2} \mathrm{O}\right], \tau_{0}=6.82 \times 10^{-7} \mathrm{~s}$ and $\mathrm{U}_{\text {eff }}=41.7 \mathrm{~K}\left(28.9 \mathrm{~cm}^{-1}\right)$, values that compares well with what observed in the literature. ${ }^{52}$ At low temperature the relaxation times saturates around $0.1 \mathrm{~s}$ as a consequence of the onset of a temperature independent relaxation. It can be noted that no reliable fitting considering Raman relaxation or is combination with Orbach and/or quantum tunneling regimes could be obtained.
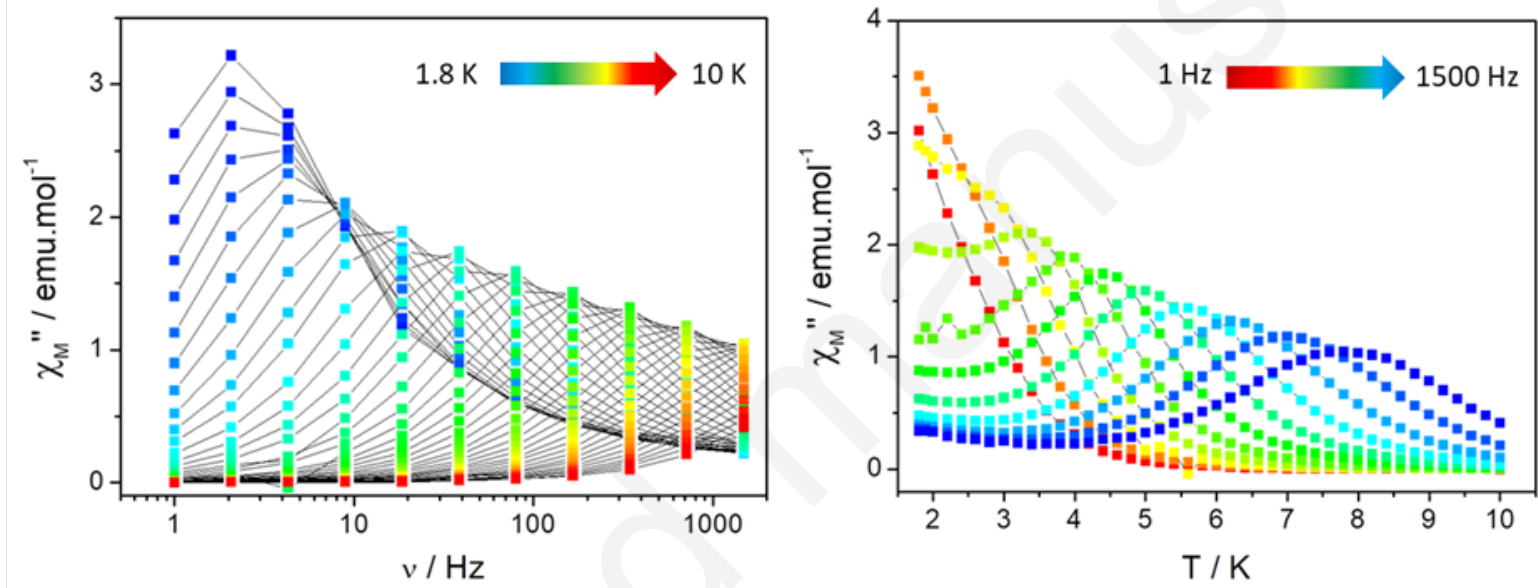

Figure 8. Frequency (left) and temperature dependence (right) of the out-of phase magnetic susceptibility $\chi_{\mathrm{M}}$ " of $\left[\mathrm{Dy}_{2}\left(\mathrm{C}_{7} \mathrm{H}_{5} \mathrm{O}_{2}\right)_{4}\left(\mathrm{C}_{7} \mathrm{O}_{4} \mathrm{H}_{6} \mathrm{~B}\right)_{2} \cdot 4 \mathrm{H}_{2} \mathrm{O}\right]$ measured with a static magnetic field $\mathrm{H}_{\mathrm{dc}}=1200$ Oe.

On $\left[\mathrm{Dy}_{2}\left(\mathrm{C}_{7} \mathrm{H}_{5} \mathrm{O}_{2}\right)_{4}\left(\mathrm{C}_{7} \mathrm{O}_{4} \mathrm{H}_{6} \mathrm{~B}\right)_{2} \cdot 4 \mathrm{H}_{2} \mathrm{O}\right]$, the distribution of the relaxation times is moderate (Figure 9, Table S5) with $\alpha$ that ranges between $\alpha=0.2$ and 0.01 (the lower is $\alpha$, the less distributed is the magnetic relaxation, with $0<\alpha<1$ ). Moreover the relaxing fraction (RF), calculated as $R F=1-\left(\chi_{S} / \chi_{T}\right)$ is quite high $\left(\chi_{S}\right.$ and $\chi_{T}$ are the adiabatic and isothermal susceptibility respectively). $\mathrm{RF}_{(2 \mathrm{~K})}=80 \%$ and $\mathrm{RF}_{(9 \mathrm{~K})}=62 \%$. This means that most of the sample relaxes slowly (high RF), with almost one single relaxation time (low $\alpha$ ). 

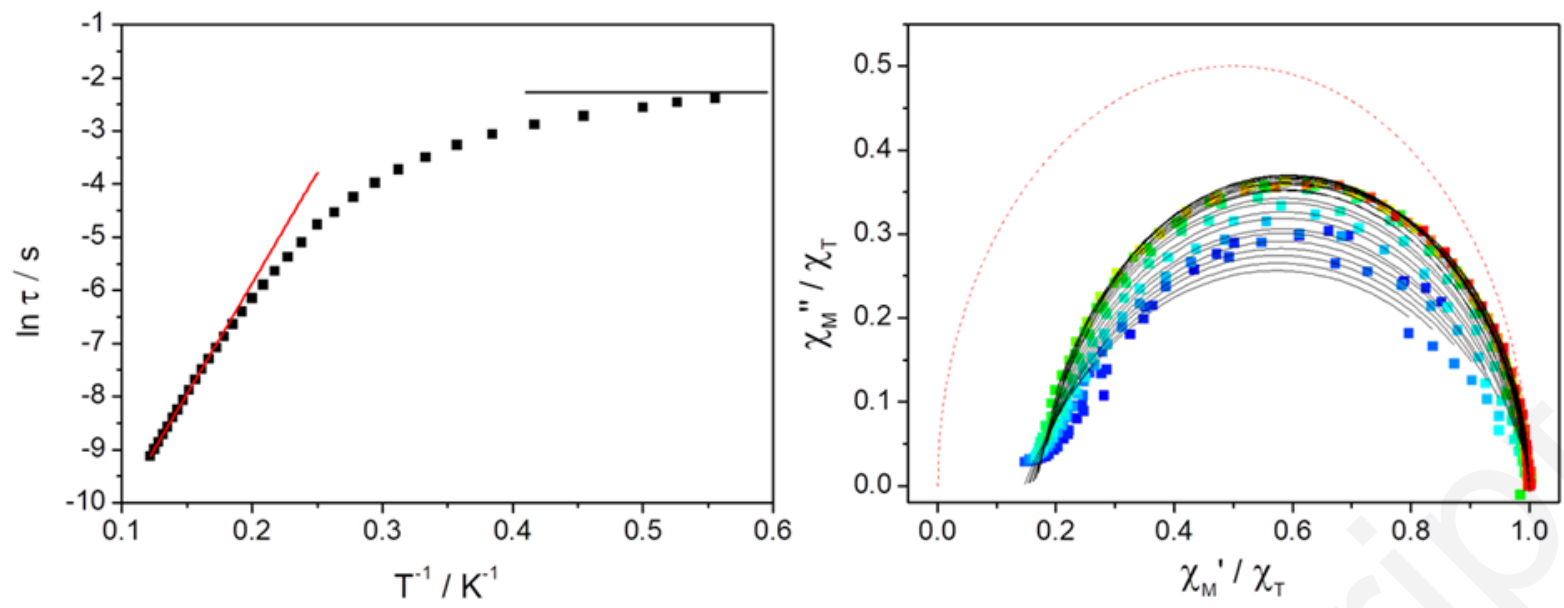

Figure 9. (left) Arrhenius plot of the relaxation times measured on [ $\mathrm{Dy}_{2}\left(\mathrm{C}_{7} \mathrm{H}_{5} \mathrm{O}_{2}\right)_{4}\left(\mathrm{C}_{7} \mathrm{O}_{4} \mathrm{H}_{6} \mathrm{~B}\right)_{2} \cdot 4 \mathrm{H}_{2} \mathrm{O}$ ] with best fit of the linear region (red line) and extrapolation of the low temperature region (black line). (right) Cole-Cole plot of the magnetic susceptibilities of $\left[\mathrm{Dy}_{2}\left(\mathrm{C}_{7} \mathrm{H}_{5} \mathrm{O}_{2}\right)_{4}\left(\mathrm{C}_{7} \mathrm{O}_{4} \mathrm{H}_{6} \mathrm{~B}\right)_{2} \cdot 4 \mathrm{H}_{2} \mathrm{O}\right]$ with best fits as black lines and ideal relaxation curve $(\alpha=0, \mathrm{RF}=100 \%)$ as red dotted line.

\section{CONCLUSION AND OUTLOOK.}

In this paper we report two new crystal structures of compounds based on boronic derivatives. Lanthanide based-complexes that are described were unexpected. However they present interesting luminescent and magnetic properties. These results evidence that boronic ligands are good candidates for lanthanide coordination chemistry.

\section{SUPPORTING INFORMATION}

Experimental and simulated X-ray powder diffraction diagrams of $\mathrm{Na}$ (o-cpb) $\mathrm{H}_{2} \mathrm{O}$; Crystal structure description of $\mathrm{Na}(\mathrm{o}-\mathrm{cpb})$; TGA/DSC curves of $\mathrm{Na}(\mathrm{o}-\mathrm{cpb}) \mathrm{H}_{2} \mathrm{O}$; UV-vis liquid state absorption spectrum of an aqueous diluted solution of $\mathrm{Na}(\mathrm{o}-\mathrm{cpb}) \mathrm{H}_{2} \mathrm{O}$; Thermal analysis (TG/TD) of $\left[\mathrm{Tb}_{2}\left(\mathrm{C}_{7} \mathrm{H}_{5} \mathrm{O}_{2}\right)_{4}\left(\mathrm{C}_{7} \mathrm{O}_{4} \mathrm{H}_{6} \mathrm{~B}\right)_{2} \cdot 4 \mathrm{H}_{2} \mathrm{O}\right]$; Temperature dependence of [Dy $2\left(\mathrm{C}_{7} \mathrm{H}_{5} \mathrm{O}_{2}\right)_{4}\left(\mathrm{C}_{7} \mathrm{O}_{4} \mathrm{H}_{6} \mathrm{~B}\right)_{2} \cdot 4 \mathrm{H}_{2} \mathrm{O}$ ] measured with a static de field of 1000 Oe; Field dependence of the out-of phase magnetic susceptibility $\chi_{\mathrm{m}}$ ” of [Dy $2\left(\mathrm{C}_{7} \mathrm{H}_{5} \mathrm{O}_{2}\right)_{4}\left(\mathrm{C}_{7} \mathrm{O}_{4} \mathrm{H}_{6} \mathrm{~B}\right)_{2} \cdot 4 \mathrm{H}_{2} \mathrm{O}$ ] measured at $2 \mathrm{~K}$ from 0 Oe to 3200 Oe; Frequency and temperature dependence of the in-phase magnetic susceptibility $\chi_{\mathrm{M}}$ ' of 
[Dy2 $\left(\mathrm{C}_{7} \mathrm{H}_{5} \mathrm{O}_{2}\right)_{4}\left(\mathrm{C}_{7} \mathrm{O}_{4} \mathrm{H}_{6} \mathrm{~B}\right)_{2} \cdot 4 \mathrm{H}_{2} \mathrm{O}$ ] measured with a static magnetic field $\mathrm{H}_{\mathrm{dc}}=1200$ Oe; Continuous Shape Measurements $(\mathrm{CShM})$ for $\left[\mathrm{Dy}_{2}\left(\mathrm{C}_{7} \mathrm{H}_{5} \mathrm{O}_{2}\right)_{4}\left(\mathrm{C}_{7} \mathrm{O}_{4} \mathrm{H}_{6} \mathrm{~B}\right)_{2} \cdot 4 \mathrm{H}_{2} \mathrm{O}\right]$; Relaxation times extracted for $\left[\mathrm{Dy}_{2}\left(\mathrm{C}_{7} \mathrm{H}_{5} \mathrm{O}_{2}\right)_{4}\left(\mathrm{C}_{7} \mathrm{O}_{4} \mathrm{H}_{6} \mathrm{~B}\right)_{2} \cdot 4 \mathrm{H}_{2} \mathrm{O}\right]$ with $\mathrm{H}_{\mathrm{dc}}=1200 \mathrm{Oe}$; Adiabatic $\left(\chi_{\mathrm{S}}\right)$, isothermic $\left(\chi_{\mathrm{T}}\right)$ susceptibility values and relaxation times distribution $(\alpha)$ extracted for [Dy $2\left(\mathrm{C}_{7} \mathrm{H}_{5} \mathrm{O}_{2}\right)_{4}\left(\mathrm{C}_{7} \mathrm{O}_{4} \mathrm{H}_{6} \mathrm{~B}\right)_{2} \cdot 4 \mathrm{H}_{2} \mathrm{O}$ ] with $\mathrm{H}_{\mathrm{dc}}=1200$ Oe. 


\section{REFERENCES.}

1. Bunzli, J.-C. G.; Piguet, C., Taking advantage of luminescent lanthanide ions. Chemical Society Reviews 2005, 34, 1048-1077.

2. Bünzli, J. C. G., Benefiting from the unique properties of lanthanide ions. Accounts Chem. Res. 2006, 39, 53-61.

3. Comby, S.; Bünzli, J. C. G.; Gschneider, K. A.; Pecharsky, V. K., Lanthanide Near-Infrared Luminescence in Molecular Probes and Devices. In Handbook on the Physics and Chemistry of Rare Earths, Elsevier: Amsterdam, 2007; Vol. 37, p 1-353.

4. Bünzli, J.-C. G.; Comby, S.; Chauvin, A.-S.; Vandevyver, C. D. B., New opportunities for lanthanide luminescence. J. Rare Earths. 2007, 25, 257-274.

5. Eliseeva, S. V.; Bünzli, J. C. G., Lanthanide luminescence for functionnal materials and biosciences. Chem. Soc. Rev. 2010, 39, 189-227.

6. Bünzli, J.-C. G., Lanthanide luminescence for biomedical analyses and imaging. Chem. Rev. 2010, 111, 2729-2755.

7. Eliseeva, S. V.; Bünzli, J. C. G., Rare earths : jewels for functionnal materials of the future. New J. Chem. 2011, 35, 1165-1176.

8. Bünzli, J. C. G., Rising stars in science and technology : Luminescent lanthanide materials. Eur. J. Inorg. Chem. 2017, 5058-5063.

9. Binnemans, K., Lanthanide based luminescent hybrid materials. Chem. Rev. 2009, 109, 42834374.

10. Cui, Y.; Yue, Y.; Qian, G.; Chen, B., Luminescent Functional Metal-Organic Frameworks. Chem. Rev. 2012, 1126-1162.

11. Cui, Y.; Li, B.; He, H.; Zhou, W.; Chen, B.; Qian, G., Metal-organic frameworks as platforms for functionnal materials. Accounts Chem. Res. 2016, 49, 483-493.

12. Cui, Y.; Zhang, J.; He, H.; Qian, G., Photonic functional metal-organic frameworks. Chem. Soc. Rev. 2018, 47, 5740-5785.

13. Guillou, O.; Daiguebonne, C.; Calvez, G.; Bernot, K., A long journey in lanthanide chemistry : from fundamental crystallogenesis studies to commercial anti-counterfeiting taggants. Accounts Chem. Res. 2016, 49, 844-856.

14. Guillou, O.; Daiguebonne, C., Lanthanide ions containing coordination polymers. In Handbook on the Physics and Chemistry of Rare Eaths (vol 34), Gschneider, K. A.; Bünzli, J. C. G.; Pecharsky, V. K., Eds. Elsevier: Amsterdam, 2005; Vol. 34, p 359-404.

15. Qiu, Y.; Daiguebonne, C.; Liu, J.; Zeng, R.; Kerbellec, N.; Deng, H.; Guillou, O., Four threedimensionnal lanthanide coordination polymers constructed from benzene-1,4-dioxyacetic acid. Inorg. Chim. Acta 2007, 360, 3265-3271.

16. Luo, Y.; Bernot, K.; Calvez, G.; Freslon, S.; Daiguebonne, C.; Guillou, O.; Kerbellec, N.; Roisnel, T., 1,2,4,5-benzene-tetra-carboxylic acid : A versatile ligand for high dimensionnal lanthanide-based coordination polymers. Cryst. Eng. Comm. 2013, 15, 1882-1896.

17. Luo, Y.; Zheng, Y.; Calvez, G.; Freslon, S.; Bernot, K.; Daiguebonne, C.; Roisnel, T.; Guillou, O., Synthesis, crystal structure and luminescent properties of new lanthanide-containing coordination polymers Involving 4,4'-oxy-bis-benzoate as Ligand. Cryst. Eng. Comm. 2013, 15, 706-720.

18. Sene, S.; Pizzoccaro, M. A.; Vezzani, J.; Reinholdt, M.; Gaveau, P.; Berthomieu, D.; Bégu, S.; Gervais, C.; Bonhomme, C.; Renaudin, G.; Mesbah, A.; van der Lee, A.; Smith, M. E.; Laurencin, D., Coordination networks based on boronate and benzoxaborolate ligands. Crystals 2016, 6, 48-61.

19. Berthomieu, D.; Gervais, C.; Renaudin, G.; Reinholdt, M.; Sene, S.; Smith, M. E.; Bonhomme, C.; Laurencin, D., Coordination polymers based on alkylboronate ligands: synthesis, characterization, and computational modelling. Eur. J. Inorg. Chem. 2015, 1182-1191.

20. Reinholdt, M.; Croissant, J.; Di Carlo, L.; Granier, D.; Gaveau, P.; Bégu, S.; Devoisselle, L.-M.; Mutin, P. H.; Smith, M. E.; Bonhomme, C.; Gervais, C.; van der Lee, A.; Laurencin, D., Synthesis and characterization of crystalline structures based on phenylboronate ligands bound to alkaline earth cations. Inorg. Chem. 2011, 50, 7802-7810. 
21. Ding, S.-Y.; Wang, W., Covalent organic frameworks (COFs): from design to applications. Chem. Soc. Rev. 2013, 42, 548-568.

22. Lekshmi, N. S.; Pedireddi, V. R., First study of metal hybrids of boronic acis : Second sphere coordination networks in the structures of 4-carboxyphenylboronic acid with some transition metal ions. Inorg. Chem. 2006, 45, 2400-2402.

23. Abdallah, A.; Freslon, S.; Fan, X.; Rojo, A.; Daiguebonne, C.; Suffren, Y.; Bernot, K.; Calvez, G.; Roisnel, T.; Guillou, O., Lanthanide based coordination polymers with 1,4 carboxyphenylboronic ligand: multi emissive compounds for multi sensitive luminescent thermometric probes. Inorg. Chem. 2019, 58, 462-475.

24. Fan, X.; Freslon, S.; Daiguebonne, C.; Le Polles, L.; Calvez, G.; Bernot, K.; Guillou, O., A family of lanthanide based coordination polymers with boronic acid as ligand. Inorg. Chem. 2015, 54, 55345546.

25. Yang, Z.-R.; Wang, M. M.; Wang, X.-S.; Yin, X.-B., Boric-acid-functional lanthanide metal-organic frameworks for selective ratiometric fluorescence detection of fluoride ions. Anal. Chem. 2017, 89, 1930-1936.

26. Desreux, J. F., In Lanthanide Probes in Life, Chemical and Earth Sciences, Choppin, G. R.; Bünzli, J. C. G., Eds. Elsevier: Amsterdam, 1989; Vol. Elsevier, p 43.

27. Kraus, W.; Nolze, G., POWDER CELL - A program for the representation and manipulation of crystal structures and calculation of the resulting X-ray powder patterns. J. Appl. Crystallogr. 1996, 29, 301-303.

28. Roisnel, T.; Rodriguez-Carjaval, J., A Window Tool for Powder Diffraction Patterns Analysis. J. Mater. Sci. Forum 2001, 378, 118-123.

29. Roisnel, T.; Rodriguez-Carjaval, J., WinPLOTR : a windows tool for powder diffraction pattern analysis. Materials Science Forum, Proceedings of the Seventh European Powder Diffraction Conference (EPDIC 7) 2000, 118-123.

30. Altomare, A.; Burla, M. C.; Camalli, M.; Carrozzini, B.; Cascarano, G.; Giacovazzo, C.; Guagliardi, A.; Moliterni, A. G. G.; Polidori, G.; Rizzi, A. C., EXPO: a program for full powder pattern decomposition and crystal structure solution. J. Appl. Crystallogr. 1999, 32, 339-340.

31. Sheldrick, G. M.; Schneider, T. R., SHELXL : High-Resolution Refinement. Macromol. Crystallogr. B 1997, 319-343.

32. Farrugia, L. J., WinGX and ORTEP for Windows: an update. J. Appl. Crystallogr. 2012, 45, 849854.

33. Farrugia, L. J., WinGX suite for smallmolecule single-crystal crystallography. J. Appl. Crystallogr. 1999, 32, 837-838.

34. Sluis, P.; Spek, A. L., BYPASS: an Effective method for the refinement of crystal structures containing disordered solvent regions. Acta Crystallogr. A 1990, A46, 194-201.

35. Chauvin, A. S.; Gumy, F.; Imbert, D.; Bünzli, J. C. G., Europium and terbium tris(dipicolinate) as secondary standards for quantum yield determination. Spectrosc Lett 2004, 37, 512-532.

36. Aebischer, A.; Gumy, F.; Bünzli, J. C. G., Intrinsic quantum yields and radiative lifetimes of lanthanide tris(dipicolinates). Phys Chem Chem Phys 2009, 11, 1346 - 1353.

37. Shi, F. N.; Cunha-Silva, L.; Trindade, T.; Paz, F. A. A.; Rocha, J., 3D lanthanide organic frameworks based on di-, tetra-, and hexameric clusters. Cryst. Growth Des. 2009, 9, 2098-2109.

38. Prodi, L.; Maestri, M.; Ziessel, R.; Balzani, V., Luminescent $\mathrm{Eu}^{3+}, \mathrm{Tb}^{3+}$ and $\mathrm{Gd}^{3+}$ complexes of a branched triazacyclononane ligand containing three 2,2'bipyridine units. Inorg. Chem. 1991, 30, 3798-3802.

39. Bünzli, J. C. G.; Eliseeva, S. V., Basics of lanthanide photophysics. In Lanthanide Luminescence, Hänninen, P.; Härmä, H., Eds. Springer Berlin Heidelberg: 2010; Vol. 7, p 1-45.

40. van der Tol, E. B.; van Ramesdok, H. J.; Verhoeven, J. W.; Steemers, F. J.; Kerver, E. G.; Verboom, W.; Reinhoudt, D. N., Tetraazatriphenylenes as Extremely Efficient Antenna Chromophoresfor Luminescent Lanthanide Ions. Chem. - Eur. J. 1998, 4, 2315-2322. 
41. Steemers, F. J.; Verboom, W.; Reinhoudt, D. N.; Van der Tol, E. B.; Verhoeven, J. W., New sensitizer-modified calix[4]arenes enabling Near-UV Excitation of complexed luminescent lanthanide ions. J. Am. Chem. Soc. 1995, 117, 9408-9414.

42. Weissman, S. I., Intramolecular energy transfer - The fluorescence of complexes of europium. J. Chem Phys 1942, 10, 214-217.

43. Guo, H.-B.; He, F.; Gu, B.; Liang, L.; Smith, J. C., Time-dependent density functionnal theory assesment of UV absorption of benzoic derivatives. The Journal of Physical Chemistry A 2012, 116, 11870-11879.

44. Acuna, A. U.; Ceballos, A.; Molera, M. J., Luminescence of benzoic acid and methyl nenzoate at 77K. Journal of the Chemical Society Faraday Transactions I/ 1975, 1469-1471.

45. Latva, M.; Takalo, H.; Mukkala, V.-M.; Matachescu, C.; Rodriguez-Ubis, J. C.; Kankare, J., Correlation between the lowest triplet state energy level of the ligand and lanthanide luminescence quantum yields. J. Lumin. 1997, 75, 149-169.

46. D'Aléo, A.; Pointillart, F.; Ouahab, L.; Andraud, C.; Maury, O., Charge transfer excited states sensitization of lanthanide emitting from the visible to near infra red. Coord. Chem. Rev. 2012, 256, 1604-1620.

47. Freslon, S.; Luo, Y.; Calvez, G.; Daiguebonne, C.; Guillou, O.; Bernot, K.; Michel, V.; Fan, X., Influence of photo-induced electron transfer on lanthanide-based coordination polymers luminescence : A comparison between two pseudo-isoreticular molecular networks. Inorg. Chem. 2014, 53, 1217-1228.

48. Fan, X.; Freslon, S.; Daiguebonne, C.; Calvez, G.; Le Polles, L.; Bernot, K.; Guillou, O., Heteronuclear lanthanide-based coordination polymers exhibiting tunable multiple emission spectra. J. Mater. Chem. C 2014, 5510-5525.

49. Galaup, C.; Couchet, J.-M.; Bedel, S.; Tisnès, P.; Picard, C., Direct access to terpyridinecontaining polyazamacrocycles as photosensitizing ligands for $\mathrm{Eu}(\mathrm{III})$ luminescence in aqueous media. J. Org. Chem. 2005, 70, 2274-2284.

50. Ward, M. D., Transition metal sensitized near infrared luminescence from lanthanide in d-f heteronuclear arrays. Coord. Chem. Rev. 2007, 251, 1663-1677.

51. Benelli, C.; Gatteschi, D., Introduction to Molecular Magnetism: From Transition Metals to Lanthanides. Wiley: 2015.

52. Habib, F.; Murugesu, M., Lessons learned from dinuclear lanthanide nan_magnets. Chem. Soc. Rev. 2013, 42, 3278-3288.

53. Perfetti, M.; Gysler, M.; Rechkemmer-Patalen, Y.; Zhang, P.; Tastan, H.; Fischer, F.; Netz, J.; Frey, W.; Zimmermann, L. W.; Schleid, T.; Hakl, M.; Orita, M.; Ungur, L.; Chibotaru, L.; BrockNannestad, T.; Piligkos, S.; van Slageren, J., Determination of the electronic structure of a dinuclear dysprosium single molecule magnet without symmetry idealization. Chem. Sci. 2019, 10, 2101-2110.

54. Giansiracusa, M. J.; Moreno-Pineda, E.; Hussain, R.; Marx, R.; Martinez Prada, M.; Negebauer, P.; Al-Badran, S.; Collison, D.; Tuna, F.; van Slageren, J.; Carretta, S.; Guidi, T.; Mc Innes, E. J. L.; Winpenny, R. E. P.; Chilton, N. F., Measurements of magnetic exchange in asymmetric lanthanide dimetallics: Toward a transferable theoritical framework. J. Am. Chem. Soc. 2018, 140, 2504-2513.

55. Yi, X.; Pointillart, F.; Le Guennic, B.; Jung, J.; Daiguebonne, C.; Calvez, G.; Guillou, O.; Bernot, $\mathrm{K}$., Rational engineering of dimeric Dy-based single molecule magnet for surface grafting. Polyhedron 2019, 164, 41-47.

56. Huang, G.; Yi, X.; Jung, J.; Guillou, O.; Cador, O.; Pointillart, F.; Le Guennic, B.; Bernot, K., Optimization of magnetic relaxation and isotopic enrichment in Dylll single molecule magnets. Eur. J. Inorg. Chem. 2018, 2018, 326-332.

57. Cimatti, I.; Yi, X.; Sessoli, R.; Puget, M.; Le Guennic, B.; Jung, J.; Guizouarn, T.; Magnani, A.; Bernot, K.; Mannini, M., Chemical tailoring of single molecule magnet behavior in films of Dy(III) dimers. Applied Surface Science 2018, 2018, 7-14.

58. Yi, X.; Calvez, G.; Daiguebonne, C.; Guillou, O.; Bernot, K., Rational organization of lanthanidebased SMMs dimers into three dimensional networks. Inorg. Chem. 2015, 54, 5213-5219. 
59. Yi, X.; Bernot, K.; Pointillart, F.; Poneti, G.; Calvez, G.; Daiguebonne, C.; Guillou, O.; Sessoli, R., A Luminescent and Sublimable DyllI-Based Single-Molecule Magnet. Chem. - Eur. J. 2012, 18, 1137911387.

60. Alvarez, S., Polyhedra in (inorganic) chemistry. Dalton Trans. 2005, 2209-2233.

61. Alvarez, S.; Alemany, P.; Casanova, D.; Cirera, J.; Llunell, M.; Avnir, D., Shape maps and polyhedral interconversion paths in transition metal chemistry. Coord. Chem. Rev. 2005, 249, 16931708.

62. Chilton, N. F.; Collison, D.; Mclnnes, E. J. L.; Winpenny, R. E. P.; Soncini, A., An electrostatic model for the determination of magnetic anisotropy in dysprosium complexes. Nat Commun 2013, 4. 63. Jung, J.; Le Natur, F.; Cador, O.; Pointillart, F.; Calvez, G.; Daiguebonne, C.; Guillou, O.; Guizouarn, T.; Le Guennic, B.; Bernot, K., Experimental and theoritical evidences that electrostatics governs easy axis orientation in DyllI-based molecular chains. Chem. Comm. 2014, 50, 13346-13348.

64. Jiang, S.-D.; Qin, S.-X., Prediction of the quantisized axis of rare earth ions: the electrostatic model with displaced point charges. Inorg. Chem. Front. 2015, 2, 613-619.

65. Bolvin, H.; Alessandri, R.; Zulfikri, H.; Autschbach, J., Crystal field in rare earth complexes: from electrostatics to bonding. Chem. - Eur. J. 2018, 24, 5538-5550.

66. Jung, J.; Yi, X.; Huang, G.; Calvez, G.; Daiguebonne, C.; Guillou, O.; Cador, O.; Caneschi, A.; Roisnel, T.; Le Guennic, B.; Bernot, K., Analysis of the electrostatics in Dylll single molecule magnet:

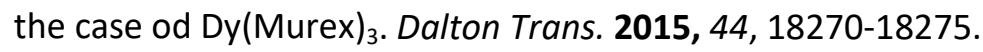

67. Cole, K. S.; Cole, R. H., Dispersion and absorption in dielectrics I. Alternating current characteristics. Journal of Chemical Physics 1941, 9, 341-351. 
TABLE OF CONTENT.

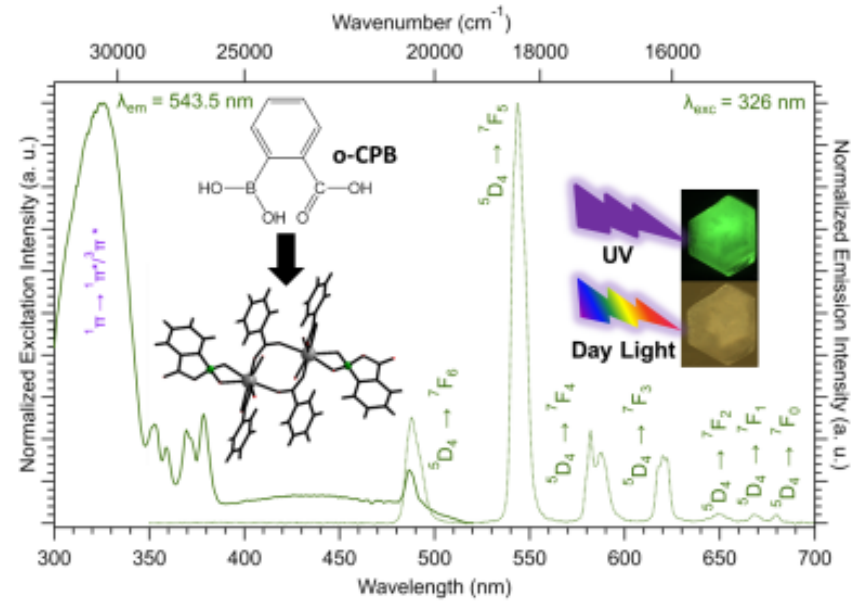

